\title{
The Role of Military Education and Task Experience of Warrior Performance
}

\author{
Bambang Sujarwo ${ }^{1}$, Nuddin Harahab ${ }^{2}$, Fadillah Putra ${ }^{3}$ \\ ${ }^{1,2,3}$ Master of Management Program \\ Brawijaya University Malang \\ Indonesia
}

\begin{abstract}
This study aimed to analyze and explain the effect of military education and task experience simultaneously on Soldier Performance, the effect of military education on Soldier Performance, and the effect of task experience on Soldier Performance. The sample of this study was 80 soldiers. The analysis technique uses multiple regression analysis. The analysis results show that military education and task experience simultaneously have a significant effect on the performance of the officers and noncommissioned officers. Military education has a significant effect on the performance of both Officer and soldiers. Task experience has a significant effect on soldiers' performance both for soldiers as a whole, officers and non-commissioned officers / enlisted men.
\end{abstract}

Keywords: Military Education, Task Experience, Soldier Performance.

\section{INTRODUCTION}

The existence of a nation and state at the global level today is inseparable from the nation's ability to protect itself from various threats and disturbances to internal and external security. For this purpose, in the constitutional concept, it is necessary to have an apparatus with responsibility and authority in national defense. The defense sector in a country has a very high role in maintaining the country's sovereignty and territorial integrity and providing safety protection to the people of the country itself. In this concept in Indonesia, we recognize the existence of the Indonesian National Army or Tentara Nasional Indonesia (TNI) institution, which is directly under the Ministry ( Ministry of Defense of the Republic of Indonesia). The existence of the TNI in Indonesian state institutions is an inseparable part of a more extensive administrative system. This is related to the existence of the TNI, which is supported by the apparatus as the leading implementer .

Good job performance is one of the goals of the organization in achieving high work productivity. A person's performance is a combination of abilities, efforts, and opportunities that can be measured from its results. Increasing performance in itself is not an easy thing. The organization's management often finds it difficult to identify what causes the performance of soldiers to decline. This is complexity of the causes of the decrease in the performance of the soldiers. Also, sometimes it is not the same cause of a soldier's performance decline with other soldiers. Even though organizational management has provided a transparent measurement tool for measuring performance, it still does not guarantee that the results can be accurate. This situation does not mean that improving performance cannot be pursued by organizational management. The performance of a good soldier can affect the overall performance of the organization.

For this reason, special attention is needed to make efforts that can improve the performance of soldiers. Not only that, but the organization must also pay attention to the factors that become obstacles so that it can cause the performance of soldiers to decline. One of the factors that cause the performance of soldiers to decline is military education.

Military education is critical in producing qualified soldiers needed by an organization or unit. Military education is critical because, through a military person's education, it can increase his ability to become a professional carried out based on a measured and integrated program consisting of knowledge, skills, and attitudes towards his students. Military education must be able to carefully combine the novelty elements in the general education system with the traditional values that have been used by the military so far. According to [1], education is an effort to develop human resources, significantly to develop human resources, 
especially to develop intellectual abilities and human personality. The pattern of military education in Indonesia, which has been implemented so far, basically aims to improve the quality of soldiers' resources so that each soldier has knowledge and skills, high discipline, a healthy body, and Pancasila spirit Sapta Marga, and Oath. The results of research by Ningrum et al. (2013) found that education affects employee performance. Pakpahan et al. (2016) proved that education affects employee performance. Furthermore, Ratnasari et al. (2018) found that education affects employee performance. However, the results of research by Mandang et al. (2017) state that education level does not affect performance.

The task experience also affects the soldier's performance. For soldiers, the task experience is a valuable provision for future assignments. Task experience can be the best teacher in capacity building. Future assignments can be carried out better and more successfully. Meanwhile, for soldiers who have never carried out an operational task, the assignment will be a precious experience to support a soldier's career. According to [2], experiences that can influence organisms' behavior can be considered learning opportunities. The learning result from the task experience will make the soldier work more effectively and efficiently. The experience would shape the knowledge and skills and attitudes that are more integrated with the soldier in the field of work handled while still working in a similar field that will eventually form the specialization of work experience gained while the soldier is working in the organization from entry to the present. Also, the experience can be obtained from previous workplaces with the same field of work that is being faced. Much or at least the experience of the task will determine or show how the quality and productivity of the soldiers in work, meaning that how easy it is or how slow the soldiers are in doing a job will be influenced by how many soldiers have had experience in carrying out a job. This means the experience will also affect the soldier's performance. The results of research by [3] prove that work experience affects employee performance. The research results by [16] also state that work experience affects employee performance. In contrast to [4] research, which states that work experience does not affect employee performance.

The purpose of this study was to analyze and explain the effect of military education and task experience simultaneously on Soldier Performance, analyze and explain the effect of military education on Soldier Performance, and analyze and explain the effect of task experience on Soldier Performance.

\section{LITERATURE REVIEW}

Work is closely related to performance. Understanding performance, it seems necessary to understand the origin of the word performance. Performance is a translation of the word performance, which comes from the root word to perform. [5] tries to provide some understanding of the performance of the experts. Another definition of performance is given by As'ad. Performance is a person's success in carrying out a job. [6] defines performance as the results of a person or group's work/activity function in an organization influenced by various factors to achieve organizational goals within a specific period. The performance is the result or overall success rate of a person during a specific period in carrying out a task compared to various possibilities, such as standard work results, targets or targets or predetermined criteria that have been mutually agreed upon.

To examine this issue education is an attempt to increase a person's general knowledge, including the mastery of theory to decide issues related to goal achievement activities. Meanwhile, education in general, is a container or process of various components that have different functions and activities. However, there is a connection and a relationship with one another. One another in an integrated and comprehensive effort in one organic unit to achieve educational goals. Whereas narrowly speaking, education is a conscious effort to instill and develop personality, intellectual and physical aspects that are carried out in educational institutions.

According to [7], work experience is: "The process of forming knowledge or skills about the method of a job because of its involvement in the implementation of job duties." Furthermore, [8] defines work experience as: "A measure of the length of time or work period that has been taken by a person can understand the tasks of a job and have carried out well."

[9] states that experiences bring out one's potential. The full potential will emerge gradually over time in response to various experiences ". So actually, what is essential to pay attention to in this relationship is a person's ability to learn from his experiences, both sweet and bitter experiences. So, in essence, the experience is an understanding of something that is lived and by appreciating and experiencing something that is gained experience, skills, or values that are integrated into one's potential.

The regulation and implementation of welfare and security in a balanced and harmonious manner in national life as a whole based on Pancasila and the 1945 Constitution based on the insight of the archipelago. Therefore, national resilience has a function as a national life system and a primary national development pattern and has a position as a condition, doctrine, and method of solving national problems. Because the conception of national resilience is based on, describes, and implements Pancasila, the 1945 Constitution, and Wasantara, the mindset in carrying out national resilience's function and position is to use an intergalactic or systemic mindset. 
Based on the research background, theoretical analysis, and the results of previous research, which are very varied and the conceptual model of the research proposed above, the research hypothesis can be formulated as follows.

H1: Military education and work experience jointly affect the performance of soldiers

$\mathrm{H} 2$ : Military education affects the performance of soldiers

H3: Experience of duty affects the performance of soldiers

\section{RESEARCH METHOD}

\subsection{Research Variable Concept}

According to [10], performance is the result of work in quality and quantity achieved by an employee in carrying out his duties following the responsibilities assigned to him.

According to the Master Manual on Education, which was legalized by Perkasad / 14-1 / IV / 2011 on April 20, 2011, Military / Army education is to form and equip students thoroughly as professional warriors. They have the attitude and behavior of soldiers according to with Sapta Marga and the Soldier's Oath, the same knowledge and skills as well as the same body to carry out the duties assigned to him and aware of his responsibilities and obligations, which are classified into two groups, namely school education, and out-of-school education.

According to the Administrative Manual on the Use of Army Soldiers with number Kep / 798 / X / 2017 dated October 27, 2017 , the assignment is a realization of the leadership's trust in soldiers, which results in responsibility for the soldier concerned.

\subsection{Research variable}

The operational variables in this study are as follows: The soldier's performance results from the work achieved by the soldier while carrying out the duties assigned according to their responsibilities. The measurement of employee performance variables uses a combination of indicators from the Guidebook on assessing the individual performance of the TNI Army environment as follows:

Achievements in implementing activities/programs are the work results achieved by each soldier in carrying out activities or activity programs. The implementation of individual activities is an activity carried out by each soldier individually following the activities for which he is responsible. The assignment's quality is how well the assignment or work is produced or completed by each soldier for whom he is responsible.

Discipline when obeying applicable laws and regulations. Employee discipline as the employee's obedience in respecting the work agreement where the employee works. Discipline is the awareness and willingness of employees to comply with all company regulations and prevailing social norms.

Someone's initiative is related to thinking power, creativity in the form of ideas for something related to organizational goals. The nature of the initiative should get attention or a positive response from superiors. Employee initiatives are ideas that are made of their own accord without encouragement from others.

Military education is essentially a conscious effort to form and develop military / TNI AD personnel to have a strong fighting spirit and high ability in carrying out TNI AD tasks, for that educational effort within the TNI AD must always lead to the realization of balance. Between fighting spirit and professional ability (Persuasion Parent about Education / Perkasad / 14-1 / IV / 2011 dated April 20 2011). Following the necessary provisions of TNI AD education, education is classified into two, namely as follows: School education is an education given to soldiers to equip, maintain, and develop specific knowledge/skills systematically arranged and administered by educational institutions. Outside school education is given to soldiers to equip, maintain and improve specific knowledge/skills held not through school education but upgrading, counseling, and refresher.

Task experience is the level of mastery of soldiers' knowledge and skills in the job, which can be measured from the tenure and the level of knowledge and skills possessed. According to the Administrative Instructions on the Use of Army Soldiers with number Kep / 798 / X / 2017 dated October 27, 2017, work experience indicators are: Assignment of a permanent nature consisting of a tour of duty (TOD) and a tour of the area (TOA). An assignment that is not permanent is an assignment that is temporary and is time-limited and does not result in a change in the position he is holding, except for some issues.

\subsection{Population \& Sample}

The population is a generalization area consisting of objects/subjects with specific qualities and characteristics determined by the researcher to study and then draw conclusions [11]. The population in this study were all 400 Rindam V / Brawijaya soldiers consisting of 245 Marindam personnel, based on the existing population, the researcher determines what part of the study will be used as a sample due to limited time, funds, and workforce-determining the selected sample by considering the necessity to represent the entire population so that there are personnel representatives of Officer \& NCO.

The formula used in determining the sample used is the Yamane formula. Based on these calculations, the number of samples selected is 80 people while still considering officers, non-commissioned officers, and enlisted men and their educational composition.

\subsection{Data analysis}


Data analysis is an essential part of the scientific method because it can be given a meaning that is useful in solving research problems. In this study, data analysis was carried out in the following stages:

1) Descriptive Statistical Analysis and Inferential Statistics

Descriptive Statistical Analysis is intended to determine the frequency distribution in the form of the mean or average value of the respondents' answers from the questionnaire results and to describe in-depth the variables studied, namely military education, task experience, and soldier performance. Meanwhile, inferential statistical analysis is used to test the value of the variable hypothesis. Inferential statistical analysis in the study using multiple regression analysis to determine the effect of the independent variable $(\mathrm{X})$ on the dependent variable $(\mathrm{Y})$ is a multiple linear regression analysis (Multiple Regression). The multiple regression model can be written as follows: $Y=a+b_{1} X_{1}+b_{2} X_{2}+\ldots \ldots+b_{n} X_{n}+e($ Sudjana, 2002)

Based on the variables used in this study, the multiple linear regression model in this study is formulated as follows: $\mathrm{Y}=\mathrm{a}+\mathrm{b}_{1} \mathrm{X}_{1}$ $+\mathrm{b}_{2} \mathrm{X}_{2}+\mathrm{e}$

$\mathrm{Y}$ : Soldier performance; $a$ : Constants; $\mathrm{b}_{1,2}$ : Regression coefficient; $\mathrm{X}_{1}$ : Military education; $\mathrm{X}_{2}$ : Experience of assignments; e: Other variables that have an effect and are not present in this research model

The use of regression analysis as an analytical model must fulfill classical assumptions. Classical assumptions (basic assumptions) in the regression model are needed to produce an unbiased estimator. The basic assumptions are fulfilled, so the estimated coefficients obtained are not biased. On the other hand, if the basic assumptions are not met, the coefficient estimates become biased, which can lead to wrong interpretations and conclusions. The classic assumption test in this study consists of multicollinearity, heteroscedasticity, and normality.

\section{RESULTS AND DISCUSSION}

To obtain a fair and efficient predictor value from a multiple regression equation with the Ordinary Least Square method, in performing data analysis, 1 must fulfill the classical assumptions as follows:

A regression model is free from multicollinearity if the VIF (Variance Inflation Factors) value of each independent variable is less than 5 . The tolerant value is closer to 1.1 As for VIF 1 is presented in the following table:

Table 1

Multicollinearity Test Results

\begin{tabular}{|c|c|c|c|c|c|c|}
\hline \multirow{3}{*}{ Variable } & \multicolumn{6}{|c|}{ Colinearity Statistics } \\
\hline & \multicolumn{2}{|c|}{ Soldiers } & \multicolumn{2}{|c|}{ Officers } & \multicolumn{2}{|c|}{$\mathrm{NCO}$} \\
\hline & Tolerance & VIF & Tolerance & VIF & Tolerance & VIF \\
\hline Military Education & 0,535 & 1,867 & 0,483 & 2,069 & 0,603 & 1,659 \\
\hline Task Experience & 0,535 & 1,867 & 0,483 & 2,069 & 0,603 & 1,659 \\
\hline
\end{tabular}

Source: Processed data.

Based on the results of VIF calculations, it can be seen that the variables of Military Education and work experience for both soldiers as a whole, officers and non-commissioned officers / enlisted men have a VIF value $<5$. Thus it can be concluded that the regressive model does not have multicollinearity problems.

The assumption that the data is usually distributed is one of the most critical assumptions in researching regression. This test aims to test the lap, whether, in the regression model, the independent, independent, and moderate variables are normally distributed or not. The data normality can be done by looking at the distribution of data (dots on the diagonal axis of the graph, that is, if the data spreads around the diagonal line and follows the diagonal line, then the line shows the data that has been distributed abnormally. 


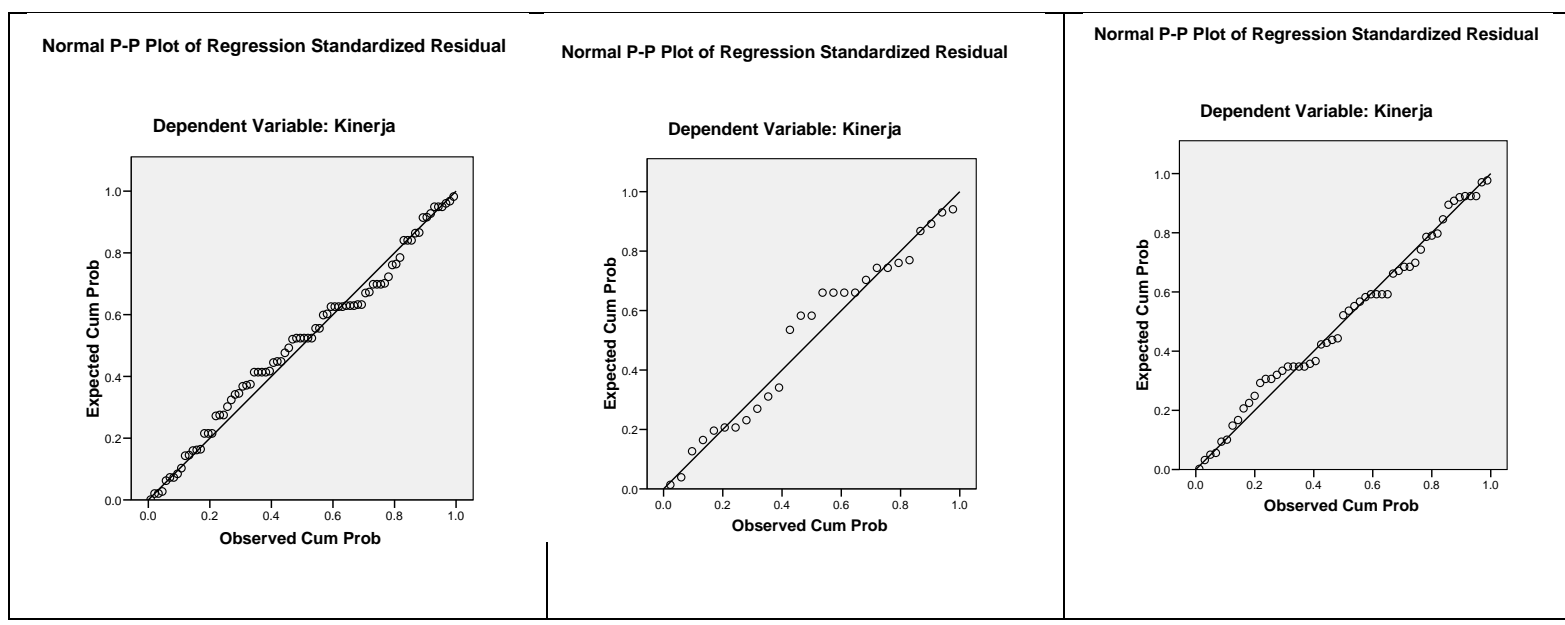

Figur 1

Data Normality (Soldiers)
Figur 2

Data Normality (Officers)
Figur 3

Data Normality (NCO)

\section{NCO: Non-commissioned officer}

FIG. 1, FIG. 2 and FIG. 3 shows that the data (dots) are spread out around and close to the diagonal line. This indicates that the research data includes the Military Education variables, and the task experience is typically distributed.

a. Heteroscedasticity

Heteroscedasticity means that the residual variability is not the same for all observations. There is a more considerable residual variation than the larger number of observations. Testing the heteroscedasticity symptom using a scatter plot, the heteroscedasticity test results are presented in the following figure.

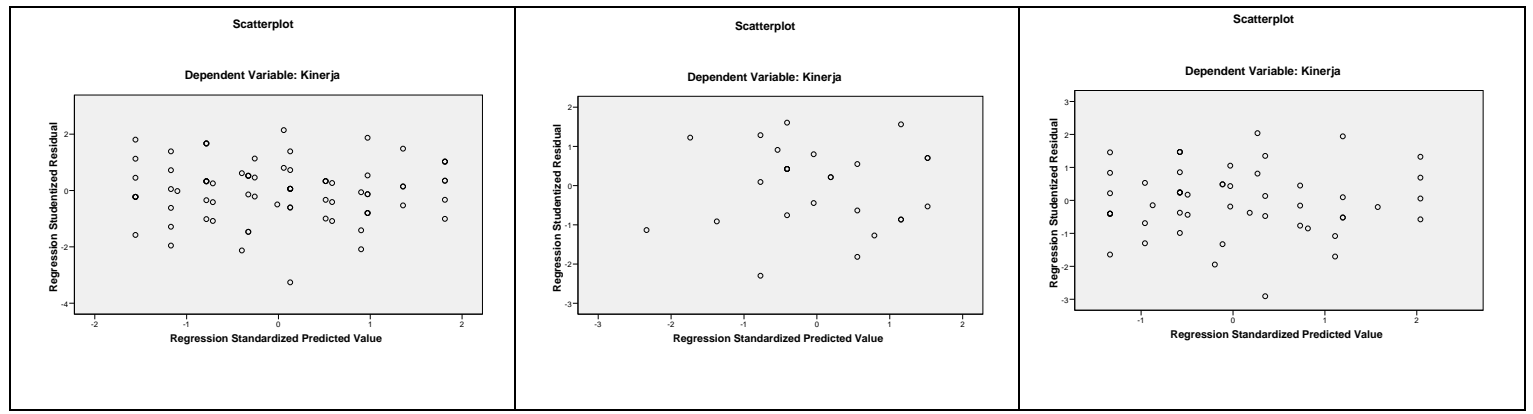

Figur 4

Uji Heteroskedastisitas Soldiers
Figur 5

Uji Heteroskedastisitas Officers
Figur 6

Uji Heteroskedastisitas NCO

Based on Figure 4, Figure 5 and Figure 6 show that the dots spread out randomly, do not form a clear, definite pattern, and are scattered both above and below the 0 anchors on the $\mathrm{Y}$-axis. This means that there is no heteroscedasticity in the regression model.

\section{The Effect of Simultaneous Military Education and Task Experience on Soldier Performance}

To analyze the effect of military education and task experience simultaneously on Soldier Performance for all soldiers, officers, and NCO / Tamtama used the F test. The Effect of Simultaneous Military Education and Task Experience on the Overall Performance of Soldiers

The F test results of the effect of military education and task experience simultaneously on the overall performance of soldiers are presented in Table 2. 
International Journal of Advances in Scientific Research and Engineering (ijasre), Vol 6 (10), October -2020

Table 2

F Test Results (All Soldiers)

\begin{tabular}{|l|c|c|c|}
\hline \multicolumn{1}{|c|}{ Variable } & $\mathrm{F}_{\text {Test }}$ & F table & Sig. \\
\hline $\begin{array}{l}\text { Military Education and Task } \\
\text { Experience }\end{array}$ & 40,040 & 3,11 & 0,000 \\
\hline
\end{tabular}

Source: Primary data processed, 2020.

Based on the results of the $F$ test calculation, it is obtained that Fount is 40.040, while $F$ table is 3.11; This means Fcount> Fable (40.040)> 3.11) while the probability value is smaller than a $=0.05(0.000<0.05)$, then I is rejected. Lha is accepted, which means that the variable is independent: Military education and experience simultaneously have a significant effect on soldiers' performance.

The Effect of Simultaneous Military Education and Task Experience on the Performance of Soldiers and Officers. The F test results of the simultaneous effect of military education and task experience on the overall performance of officer soldiers are presented in Table 3.

Table 3

F Test Result (Officer)

\begin{tabular}{|l|c|c|c|}
\hline \multicolumn{1}{|c|}{ Variable } & $\mathrm{F}_{\text {Test }}$ & F table & Sig. \\
\hline $\begin{array}{l}\text { Military Education and Task } \\
\text { Experience }\end{array}$ & 66,204 & 3,40 & 0,000 \\
\hline
\end{tabular}

Source: Primary data processed, 2020.

Based on the results of the F test calculation, it is obtained that Fount is 66.204, while Ftable is 3.40; This means $\mathrm{F}$ test > F table (66.204)> 3.40) whereas the probability value is smaller than a $=0.05(0.000<0.05)$, then who is rejected. Lha is accepted, which means that the variable is independent: Military education and work experience simultaneously have a significant effect on the officers' performance.

The Effect of Simultaneous Military Education and Task Experience on the Performance of NCO Soldiers. The F test results 'of the simultaneous effect of military education and task experience on the overall performance of NCO / Tamtama soldiers are presented in Table 4.

Table 4

F Test Results (NCO / Tamtama)

\begin{tabular}{|l|c|c|c|}
\hline \multicolumn{1}{|c|}{ Variable } & $\mathrm{F}_{\text {Test }}$ & F table & Sig. \\
\hline $\begin{array}{l}\text { Military Education and Task } \\
\text { Experience }\end{array}$ & 14,837 & 3,18 & 0,000 \\
\hline
\end{tabular}

Source: Primary data processed, 2020.

Based on the results of the F test calculation, it is obtained that Fount is 14.837 , while the F table is 3.18 ; This means $\mathrm{F}$ test $>\mathrm{F}$ table $(14.837)>3.18)$ while the probability value is smaller than a $=0.05(0.000<0.05)$, then is rejected. Ha is accepted, which means that the variable is independent: Military Education and task experience simultaneously had a significant effect on the NCO soldiers' performance.

The Effect of Military Education on Soldier Performance, To analyze military education's effect on Soldier Performance for all soldiers, officers, and NCO, regression analysis, and t-test were used. The regression analysis results of the effect of military education on the overall performance of soldiers are presented in Table 5.

Table 5

Results of Regression Analysis and t-Test (All Soldiers)

\begin{tabular}{|l|c|c|c|c|}
\hline \multicolumn{1}{|c|}{ Variable } & Regressive Coefficient & F Test & Sig. & Information \\
\hline Military Education $\left(\mathrm{X}_{1}\right)$ & 0,236 & 3,127 & 0,002 & Significant \\
\hline Dependent variable = Soldier overall performance $(\mathrm{Y})$ \\
\hline $\mathrm{t}$ table $=2,000$
\end{tabular}

Source: Primary data processed, 2020.

Based on Table 5, it can be explained that the effect of military education on the overall performance of soldiers is significant at the level of $5 \%$ indicated by the count value of 3.127 , which is greater than the t-table value of 2,000 and the p-value of 0.002 is smaller than 0.05 , and the coefficient regression of 0.236 . This means that higher military education will cause soldiers' performance to increase, assuming the variable of task experience (X2) is constant. Meanwhile, the effect of Military Education on the performance of soldiers is 0.236 . 
International Journal of Advances in Scientific Research and Engineering (ijasre), Vol 6 (10), October -2020

The regression analysis results of the effect of military education on the performance of the officer soldiers are presented in Table 6.

Table 6

Results of Regression Analysis and t-Test (Officer)

\begin{tabular}{|l|c|c|c|c|}
\hline \multicolumn{1}{|c|}{ Variable } & Regressive Coefficient & F Test & Sig. & Information \\
\hline Military Education $\left(\mathrm{X}_{1}\right)$ & 0,471 & 5,193 & 0,000 & Significant \\
\hline Dependent variable $=$ Soldier overall performance $(\mathrm{Y})$ \\
\hline $\mathrm{t}$ table $=2,064$
\end{tabular}

Source: Primary data processed, 2020.

Based on Table 6, it can be explained that the effect of military education on the overall performance of soldiers is significant at the level of $5 \%$, indicated by the t-count value of 5.193 is greater than the t-table value of 2.064 and the p-value of 0.000 less than 0.05 , and the coefficient regression of 0.471 . This means that the higher the Military Education will cause Perwiea soldiers' performance to increase, assuming the variable of task experience (X2) is constant. At the same time, the effect of Military Education on the performance of soldiers is 0.471 .

The regression analysis results of the effect of military education on the performance of the NCO / Tamtama soldiers are presented in Table 7.

Table 7

Results of Regression Analysis and t-test (Bintara / Tamtama)

\begin{tabular}{|l|c|c|c|c|}
\hline \multicolumn{1}{|c|}{ Variable } & Regressive Coefficient & $\mathrm{F}_{\text {Test }}$ & Sig. & Information \\
\hline Military Education $\left(\mathrm{X}_{1}\right)$ & 0,192 & 2,068 & 0,044 & Significant \\
\hline Dependent variable $=$ Soldier overall performance $(\mathrm{Y})$ \\
\hline $\mathrm{t}$ table $=2,000$
\end{tabular}

Source: Primary data processed, 2020.

Based on Table 7, it can be explained that the effect of military education on the overall performance of soldiers is significant at the level of $5 \%$ indicated by the count value of 2.068 , which is greater than the table value of 2,000 and the p-value of 0.044 is smaller than 0.05 , and the coefficient regression of 0.192 . This means that the higher the Military Education will cause Perwiea soldiers' performance to increase, assuming the variable of task experience (X2) is constant. Meanwhile, the effect of Military Education on the performance of soldiers was 0.192 .

Analyze the effect of task experience on Soldier Performance for all soldiers, officers, and NCO / Tamtama, regression analysis, and t-test were used. The Effect of Task Experience on the Overall Performance of Soldiers. The regression analysis results of the effect of task experience on the overall performance of soldiers are presented in Table 8 .

Table 8

Results of Regression Analysis and t-Test (All Soldiers)

\begin{tabular}{|l|c|c|c|c|}
\hline \multicolumn{1}{|c|}{ Variable } & Regressive Coefficient & $\mathrm{F}_{\text {Test }}$ & Sig. & Information \\
\hline Task experience $\left(\mathrm{X}_{2}\right)$ & 0,279 & 4,004 & 0,000 & Significant \\
\hline Dependent variable $=$ Soldier overall performance $(\mathrm{Y})$ & \\
\hline $\mathrm{t}$ table $=2,000$
\end{tabular}

Source: Primary data processed, 2020.

Based on Table 8, it can be explained that the effect of task experience on the overall performance of soldiers is significant at the level of $5 \%$, indicated by the count value of 4.004 , which is greater than the t-table value of 2,000 and the pvalue of 0,000 is smaller than 0.05 , and the coefficient regression of 0.279 . This means that the higher the task experience will cause the soldier's performance to increase, assuming the military education variable (X1) is constant. At the same time, the effect of task experience on the soldier's performance is 0.279 .

The regression analysis results of the effect of task experience on the performance of the officer soldiers are presented in Table 9. 
International Journal of Advances in Scientific Research and Engineering (ijasre), Vol 6 (10), October -2020

Table 9

Results of Regression Analysis and t-Test (Officer)

\begin{tabular}{|l|c|c|c|c|}
\hline \multicolumn{1}{|c|}{ Variable } & Regressive Coefficient & $\mathrm{F}_{\text {Test }}$ & Sig. & Information \\
\hline Task experience $\left(\mathrm{X}_{2}\right)$ & 0,287 & 3,406 & 0,002 & Significant \\
\hline Dependent variable $=$ Soldier overall performance $(\mathrm{Y})$ & \\
\hline $\mathrm{t}$ table $=2,064$
\end{tabular}

Source: Primary data processed, 2020.

Based on Table 9, it can be explained that the effect of task experience on the overall performance of soldiers is significant at the level of 5\% indicated by the count value of 3.406, which is greater than the t-table value of 2.064 and the p-value of 0.002 less than 0.05 , and the coefficient regression of 0.287 . This means that the higher the task experience will cause Perwiea soldiers' performance to experience an increase, assuming the variable of military education (X1) is constant. While the effect of task experience on the soldier's performance is 0.287 .

The regression analysis results of the effect of task experience on the performance of the NCO / Tamtama soldiers are presented in Table 10 .

Table 10

Results of Regression Analysis and t-test (Bintara / Tamtama)

\begin{tabular}{|l|c|c|c|c|}
\hline \multicolumn{1}{|c|}{ Variable } & $\begin{array}{c}\text { Regressive } \\
\text { Coefficient }\end{array}$ & $\mathrm{F}_{\text {Test }}$ & Sig. & Information \\
\hline Task experience $\left(\mathrm{X}_{2}\right)$ & 0,234 & 2,610 & 0,012 & Significant \\
\hline Dependent variable $=$ Soldier overall performance $(\mathrm{Y})$ & \\
\hline $\mathrm{t}$ table $=2,000$
\end{tabular}

Source: Primary data processed, 2020.

Based on Table 10, it can be explained that the effect of task experience on the overall performance of soldiers is significant at the level of $5 \%$ indicated by the count value of 2,610 is greater than the t-table value of 2,000 and the p-value of 0.012 is smaller than 0.05 , and the coefficient regression of 0.234 . This means that the higher the taskerience will cause Perwiea soldiers' performance to increase, assuming the military education variable (X1) is constant. At the same time, the effect of task experience on the soldier's performance is 0.234 .

\section{Hypothesis}

First Hypothesis Test

To test the first hypothesis, which states that military education and task experience jointly affect the performance of soldiers, using the $\mathrm{F}$ test. and $\mathrm{df} 2=77$ at 3.11 ; this means that $\mathrm{F}$ test $>\mathrm{F}$ table $(40.040)>3.11)$ while the probability value is smaller than $\mathrm{a}=0.05(0.000<0.05)$, so Ho is rejected. Ha is accepted, which means that the independent variables: Military Education and experience, simultaneously have a significant effect on soldiers' performance. Thus the first hypothesis is statistically accepted or tested.

Second Hypothesis Test

To test the second hypothesis, military education affects soldiers' performance, using the t-test. Based on the results of the t-test for the Military Education variable, the value of test $=3.127$ while the value of table $=2,000$ so that $t$-test $>$ table or a significance value of $0.002<0.05$ so Ho is rejected or Ha is accepted, and it is proven that the Military Education variable (X1) has a significant effect on the performance of soldiers ( Y). Thus the second hypothesis is statistically tested.

Third Hypothesis Test

To test the third hypothesis, which states that task experience affects soldiers' performance, using the t-test. Based on the results of the t-test of the task experience variable, the value of count $=4.004$ while the value of table $=2,000$ so that $\mathrm{t}$ test $>$ table or a significance value of $0.000<0.05$ so Ho is rejected or Ha is accepted, and it is proven that the task experience variable (X2) has a significant effect on the performance of soldiers ( Y). Thus the third hypothesis is statistically tested.

\section{Hypothesis Testing (Officer)}

First Hypothesis Test, To test the first hypothesis, which states that military education and task experience jointly affect soldiers' performance, using the F test. Based on the results of the calculation of the F test with SPSS, it is obtained that Fount is 66.204, while Fable is at $\mathrm{a}=5 \%$, df1 $=2$, and df2 $=24$ at 3.40; this means F test $>\mathrm{F}$ table (66.204)> 3.40) while the probability value is smaller than $\mathrm{a}=0.05(0.000<0.05)$, so Ho is rejected. Ha is accepted, which means that the independent variables: 
Military Education and experience, simultaneously have a significant effect on soldiers' performance. Thus the first hypothesis is statistically accepted or tested.

Second Hypothesis Test, To test the second hypothesis, military education affects soldiers' performance, using the t-test. Based on the results of the t-test for the Military Education variable, the value of count $=5.193$ while the value of table $=2,000$ so that t-test $>$ table or a significance value of $0.000<0.05$, so Ho is rejected or Ha is accepted, and it is proven that the Military Education variable (X1) has a significant effect on the performance of soldiers ( Y). Thus the second hypothesis is statistically tested.

Third Hypothesis Test, To test the third hypothesis, which states that task experience affects soldiers' performance, the ttest is used. Based on the results of the t-test for the task experience variable, the value of test $=3.406$ while the value of $t$ table $=$ 2,000 so that $t$-test $>t$ table or a significance value of $0.002<0.05$ so Ho is rejected or Ha is accepted, and it is proven that the task experience variable (X2) has a significant effect on the performance of soldiers ( Y). Thus the third hypothesis is statistically tested.

\section{Hypothesis Testing NCO}

First Hypothesis Test, To test the first hypothesis, which states that military education and task experience jointly affect soldiers' performance, using the F test. Based on the results of the F test calculations with SPSS, it is obtained that F count is 14.837, while $\mathrm{F}$ table is at $\mathrm{a}=5 \%$, df1 $=2$, and $\mathrm{df} 2=50$ at 3.18; this means that $\mathrm{F}$ test $>\mathrm{F}$ table (66.204)> 3.18) while the probability value is smaller than a $=0.05(0.000<0.05)$, so Ho is rejected. Ha is accepted, which means that the independent variables: Military Education and experience, simultaneously have a significant effect on soldiers' performance. Thus the first hypothesis is statistically accepted or tested.

Second Hypothesis Test, To test the second hypothesis, military education affects soldiers' performance, using the t-test. Based on the results of the t-test for the Military Education variable, the value of t-test $=2.068$ while the value of $t$ table $=2,000$ so that $\mathrm{t}$-test $>\mathrm{t}$ table or a significance value of $0.044<0.05$ so Ho was rejected or Ha was accepted, and it was proven that the Military Education variable (X1) had a significant effect on the performance of soldiers ( Y). Thus the second hypothesis is statistically tested.

Third Hypothesis Test, To test the third hypothesis, which states that task experience affects soldiers' performance, using the $\mathrm{t}$-test. Based on the results of the $\mathrm{t}$-test for the task experience variable, the value of $\mathrm{t}$-test $=2.610$ while the value of $\mathrm{t}$ table $=$ 2,000 so that $\mathrm{t}$-test $>\mathrm{t}$ table or a significance value of $0.012<0.05$ so Ho is rejected or Ha is accepted, and it is proven that the task experience variable (X2) has a significant effect on the performance of soldiers ( Y). Thus the third hypothesis is statistically tested.

\section{DISCUSSION}

\section{The Effect of Simultaneous Military Education and Task Experience on Soldier Performance}

The analysis results show that military education and task experience simultaneously affect the performance of soldiers, both for soldiers as a whole, officers and non-commissioned officers / enlisted men. This shows that the higher the level of Military Education and supported by more experience in the task can improve soldiers' performance. Soldiers who have a high level of education can more easily adapt to technological developments and the demands of science, because with their education, they become knowledge, recognize and develop methods of thinking systematically so that they can solve problems that will be faced and support the ability of soldiers to carry out their duties. Which are given? As the opinion of Pandojo and Husnan (2003) which states that education is an attempt to increase one's general knowledge, including the mastery of theory, to decide issues related to goal achievement activities. [12], [13], [14], [15], which states that education affects performance.

Task experience can help the smooth running of work in an organization. The task experience can be given to the soldiers to guide and learn the soldiers. A soldier who has more task experience can certainly better understand what to do when facing a problem. Also, these soldiers will work faster and do not have to adapt to the task being carried out because they already have the experience. The organization can more easily achieve organizational goals because it is supported by soldiers who are experienced in their respective fields. Task experience could form knowledge and skills and attitudes that are more integrated with soldiers if the field of work handled while still working in a similar field, which will eventually form a work specialization. Experienced soldiers will find it easier and faster to carry out the assigned task because they have more experience working to improve the soldier's performance. The results of this study support [14], [3], and [16], who state that experience affects performance. The results of this study support [14], which states that education and experience simultaneously have a significant effect on performance. With the better performance of Soldiers professionally in carrying out their duties it will thus support the realization of National resilience. 


\section{The Effect of Military Education on Soldier Performance}

Military education has a significant effect on soldiers' performance for soldiers, officers, and non-commissioned officers I tamtama. Education is a significant effort to improve the quality of soldiers. This can be seen from the increased knowledge and skills of soldiers, which will impact their job performance. The project is an invaluable asset to an organization. Soldiers have a significant role in every organizational activity. Without soldiers, an organization will not be able to carry out all its organizational activities, as stated by [1], which states that education is an effort to develop human resources, significantly to develop intellectual abilities and human personality. This shows that the soldier is the primary key who must be considered with all his needs. As the primary key, soldiers will determine the successful implementation of organizational activities.

In an era of increasingly advanced globalization, there is increasingly intense competition, where each organization should be able to adapt to the changes that occur and take advantage of the opportunities and challenges that arise. Each soldier must have a high ability to carry out his duties, authorities, and responsibilities according to his position: improved abilities, both professional abilities, insight skills, and leadership abilities. Fostering the quality of human resources needs to be carried out continuously and continuously so that soldiers involved can improve their performance through education. The goal to be achieved is basically to develop soldiers' ability not only to handle the work of soldiers at that time but also for jobs. Future work. The effort to develop soldiers must be given top priority because this is intended to obtain qualified soldiers. Therefore, the education program is a part that needs attention to supporting the achievement of organizational goals. Achieving the level of organizational goals and the ability to compete will depend on whether or not the educational program implemented by the organization is directed at improving abilities and performance in all positions and positions, developing skills and skills following the demands of the job. The results of this study support [12], [13], [14], [15], which states that education affects performance. However, the results do not support [17], stating that education does not affect performance. This shows that the higher the soldiers' education level, it does not necessarily improve the soldiers' performance.

\section{The Effect of Task Experience on Soldier Performance}

Task experience has a significant effect on soldiers' performance both for soldiers as a whole, officers and noncommissioned officers / enlisted men. Task experience in improving performance is needed because with sufficient experience, it can support work as the opinion of [7], which states that work experience is the process of forming knowledge or skills about the method of a job because of its involvement in the implementation of work tasks. Service experience for soldiers is significant to be applied in an organization. With the experience, it is hoped that soldiers can work more effectively and efficiently, mostly to deal with changes that occur, such as changes in technology, changes in work methods, demanding changes in attitudes, behavior, skills, and knowledge. For this reason, organizations that want to develop the experience of soldiers should get significant attention.

In general, the task experience is carried out to benefit soldiers, organizations, and society. Thus it can be said that the purpose of task experience is to develop knowledge, attitudes, work skills, and morale of soldiers to increase the workforce or performance of soldiers to produce quality work. Besides, it is also to close the gap between soldiers' workability and job demands, so that mutually beneficial conditions will be achieved both for the organization and for the soldiers. The results of this study support [4], [14[3], and [16] who state that experience affects performance.

\section{CONCLUSIONS AND RECOMMENDATIONS}

According to the results of the analysis, the researcher can make the following conclusions: Military education and task experience simultaneously have a significant effect on officers' performance and non-commissioned officers / enlisted officers. This shows that the higher the level of military education and being supported by experienced soldiers can directly improve performance, it will have implications for implementing tasks.

Military education has a significant effect on soldiers' performance both for soldiers as a whole, officers, and noncommissioned officers / enlisted men, which means that the more frequently following soldiers following Dibangspes and attending upgrades/counseling can improve the performance of soldiers.

Task experience has a significant effect on soldiers' performance both for soldiers as a whole, officers and noncommissioned officers / enlisted men, which means that the more frequent carrying out of duties / TOA and carrying out operational tasks can improve the performance of soldiers.

Based on the research results and the conclusions of this study, the suggestions that can be given are as follows: For Rindam V / Brawijaya, Based on the research results described in the description of the Military Education variable, soldiers at Rindam V / Brawijaya Malang have an adequate level of education. However, agencies need to pay attention to school education (Dikbangspes). The results showed that NCO soldiers' task experience who had experience in the assignment was in the category of less high. Therefore the leadership should provide more opportunities for NCO soldiers to carry out operational tasks, both permanent and non-permanent. 
For Future Research, Further research needs to analyze with different variables such as Welfare, Unit Tradition, and others that can improve soldiers' performance in other institutions that show different characteristics of the object of this study. In further research, it is necessary to examine more deeply by developing methods of data collection and using a questionnaire, which can be carried out by in-depth interviews so that more information can be used as a better research tool.

\section{REFERENCES}

[1] . Notoatmodjo, Soekidjo., 2008. Metodologi Penelitian Kesehatan. Edisi revisi. Jakarta: PT. Rineka Cipta.

[2] . Syah, Muhibbin, 1995, Psikologi Pendidikan Suatu Pendekatan Baru. Bandung : PT. Remaja Rosda Karya.

[3] . Bili, Wanceslaus, Erwin Resmawan dan Daud Kondorura. 2018. Pengaruh Pengalaman Kerja Terhadap Kinerja Pegawai Di Kantor Kecamatan Laham Kabupaten Mahakam Ulu. eJournal Pemerintahan Integratif. Vol. 6. No. 3: $465-474$.

[4] . Riyadi, Bagus Aries. 2015. Pengaruh Pengalaman Kerja Terhadap Kinerja Karyawan Pada Toko Emas Semar Nganjuk. Equilibrium. Volume 3, Nomor 1: $49-61$.

[5] . Mangkuprawira, Sjafri. 2007. Manajemen Mutu Sumber Daya Manusia. Bogor: Ghalia Indonesia.

[6]. Tika, Pabundu. 2008. Budaya Organisasi dan Peningkatan Kinerja Perusahaan Jakarta: Bumi. Aksara.

[7] . Manullang. 2004. Manajemen Personalia. Edisi 3, Yogyakarta: Gadjah Mada University Press.

[8] . Ranupandojo, Heidjrachman. 2001. Dasar-dasar Manajemen. Edisi Revisi, Cetakan Kedua 2. Yogyakarta: UPPAMP YJPN.

[9] . Johnson, Elaine B. PH.D. 2007. Contextual Teaching and Learning. Mizan Learning Center (MLC). Bandung.

[10] .Mangkunegara, A.A. Anwar Prabu 2002. Manajemen Sumber Daya Manusia. Perusahaan. Bandung: PT. Remaja Rosdakarya.

[11] .Sugiyono. 2010. Metode Penelitian Pendidikan Pendekatan Kuantitatif, kualitatif, dan R\&D. Bandung: Alfabeta

[12] .Ningrum, Widhayu, Bambang Swasto Sunuharyo dan Moehammad Soe'oed Hakam. 2013. Pengaruh Pendidikan dan Pelatihan Terhadap Kinerja Karyawan (Studi Pada Karyawan Joint Operating Body Pertamina-PertoChina East Java). Jurnal Administrasi Bisnis (JAB). Vol. 6 No. 2: 1-8.

[13] .Pakpahan Edi Saputra, Siswidiyanto, dan Sukanto. 2016. Pengaruh Pendidikan Dan Pelatihan Terhadap Kinerja Pegawai (Studi pada Badan Kepegawaian Daerah Kota Malang). Jurnal Administrasi Publik (JAP). Vol. 2, No. 1: $116-121$.

[14] .Devischa, Decky Candra dan Mochammad Djudi Mukzam. 2018. Pengaruh Pendidikan Dan Pengalaman Kerja Terhadap Kemampuan Kerja dan Kinerja Karyawan (Studi Pada Karyawan BRI Syariah Cabang Kediri). Jurnal Administrasi Bisnis (JAB). Vol. 63 No. 1: 107-114.

[15] .Ratnasari, Miranda Diah dan Bambang Swasto Sunuharyo. 2018. Pengaruh Pendidikan dan Pelatihan Terhadap Kinerja Karyawan Melalui Variabel Mediator Kemampuan Kerja Karyawan (Studi Pada Karyawan PT Petrokimia Gresik). Jurnal Administrasi Bisnis (JAB). Vol. 58 No.1: 210-218.

[16] .Octavianus, Wungow Raymond dan Adolfina. 2018. Pengaruh Pengalaman Kerja Dan Pelatihan Kerja Terhadap Kinerja Karyawan PT. Telkom Indonesia Cabang Manado. Jurnal Emba. Vol. 6 No. 3: 1758-1767.

[17] .Mandang, Evert Fandi, Bode Lumanauw dan Mac. D. B. Walangitan. 2017. Pengaruh Tingkat Pendidikan dan Pelatihan Terhadap Kinerja Karyawan Pada PT. Bank Rakyat Indonesia (Persero), Tbk Cabang Manado. Jurnal Emba. Vol. 5 No. 3: 4324-4335. 